\title{
RELATIONSHIP BETWEEN SNACKS AND BEVERAGES WITH THE NUTRITIONAL STATUS AMONG 'SAD' CHILDREN IN NYOGAN VILLAGE, MUARO JAMBI, JAMBI PROVINCE
}

\author{
Ummi Kalsum, Hendra Dhermawan Sitanggang
}

Study Program of Public Health, Jambi University

\begin{abstract}
Background: Malnutrition among children is still a public health problem in Jambi Province, especially in the Suku Anak Dalam (SAD) community. Most of the nutritional problems among SAD children are underweight and stunting. Malnutrition in SAD children could be related to their consumption patterns of snack and beverage. This study aimed to examine the relationship between consumption patterns of snack and beverage with the nutritional status among SAD children.

Subejects and Method: A cross sectional was conducted in Nyogan Village, Jambi. A total of $78 \mathrm{SAD}$ children aged 5-14 years was enrolled in this study using total sampling. Sample were selected using the criteria of attending Elementary School located in Transocial Village or school-age children living in the Nyogan Village. The dependent variable was nutritional status and independent variable was consumption patterns of snack and beverage. The co-variables were the pocket money, physical activity, breakfast habit, parental income, cultural factor, parental knowledge, and consumption of vegetables and fruit. Data were collected by height and weight measurements and interviews. Data were analyzed by multiple logistic regression.

Results: Most of the children were underweight children (15.4\%), overweight (10.3\%), and normal (74.4\%). The average pocket money was Rp. 5,000. 31\% children rarely have breakfast, and $58 \%$ children came from low-income parents. Consumption patterns of snack and beverage was associate with nutritional status after controlling by physical activity, breakfast habit, income, parental knowledge, and fruit consumption habit $(\mathrm{OR}=1.48 ; 95 \% \mathrm{CI}=0.26$ to $8.57 ; \mathrm{p}=0.659)$, but they were not statistically significant. The dominant factor was parental knowledge $(\mathrm{OR}=12.37 ; 95 \% \mathrm{CI}=0.55$ to $276.18 ; \mathrm{p}=0.112)$, but it was not statistically significant.

Conclusion: A poor consumption patterns of snack and beverage increased the risk of 1.48 times of underweight among SAD children. Parental knowledge is the dominant factor.
\end{abstract}

Keywords: consumption pattern, snacks, beverage, nutritional status, suku anak dalam

\section{Correspondence:}

Ummi Kalsum. Study Program of Public Health, Jambi University. Jl. Tri Brata, Km 11 Unja Campus Pondok Meja Mestong, Muaro Jambi. Email: kalzoem@gmail.com.

Mobile: 081314385775

The $7^{\text {th }}$ International Conference on Public Health

Solo, Indonesia, November 18-19, 2020 | 117

https://doi.org/10.26911/the7thicph.02.06 